\title{
Quality of sesame seeds produced under soil salinity levels ${ }^{1}$
}

\author{
Jackson Silva Nóbrega ${ }^{2}$, Kilson Pinheiro Lopes ${ }^{3}$, \\ João Batista dos Santos ${ }^{3}$, Francisco Jean da Silva Paiva ${ }^{3}$, Joseano Graciliano da Silva ${ }^{4}$, Geovani Soares de Lima ${ }^{3}$
}

\section{ABSTRACT}

Sesame is considered an alternative crop for small and medium farmers in the Brazilian Northeast region. However, under the conditions of the northeastern semi-arid region, the scarcity of good quality water for irrigation may lead to a reduction in the quality of the final product. This study aimed to evaluate the physiological quality of sesame seeds produced under levels of soil salinity. The experiment was carried out in a completely randomized design, in a $5 \times 5$ factorial scheme, with three replicates, corresponding to sesame cultivars (BRS Seda, BRS G2, BRS G3, BRS G4 and BRS Anahi) and soil salinity levels with the following values for electrical conductivity: $0.6 \mathrm{dS} \mathrm{m}^{-1}, 1.2 \mathrm{dS} \mathrm{m}^{-1}, 1.8 \mathrm{dS} \mathrm{m}^{-1}, 2.4 \mathrm{dS} \mathrm{m}^{-1}$ and $3.0 \mathrm{dS} \mathrm{m}^{-1}$. The physiological quality was characterized based on tests of germination, first germination count, germination speed index, radicle length, seed electrical conductivity, emergence, emergence speed index and seedling dry matter. BRS Seda, BRS G2 and BRS G3, cultivated under salinity levels, present seeds with a better physiological quality, demonstrating a higher tolerance to salt stress conditions. The BRS Seda and BRS G2 cultivars tolerate salinity levels of up to $2.4 \mathrm{dS} \mathrm{m}^{-1}$, while BRS G3 tolerates levels of up to $1.8 \mathrm{dS} \mathrm{m}^{-1}$. BRS G4 and BRS Anahi have the physiological quality of their seeds compromised by the increase in the soil salinity, during their production.

KEYWORDS: Sesamum indicum L.; salt stress; seed physiological quality.

\section{INTRODUCTION}

Sesame (Sesamum indicum L.) is one of the oldest oilseed crops cultivated, with a great adaptability to the climatic conditions of the Brazilian Northeast semi-arid region, where it is produced by family farmers and plays a social role in the

\section{RESUMO}

Qualidade de sementes de gergelim produzidas sob níveis de salinidade do solo

O gergelim é considerado uma cultura alternativa para pequenos e médios agricultores da região Nordeste. No entanto, nas condições do semiárido nordestino, a escassez de água de boa qualidade utilizada na irrigação pode refletir em redução na qualidade do produto final. Objetivou-se avaliar a qualidade fisiológica de sementes de gergelim produzidas sob níveis de salinidade do solo. O experimento foi conduzido em delineamento inteiramente casualizado, em esquema fatorial $5 \times 5$, com três repetições, correspondendo a cultivares de gergelim (BRS Seda, BRS G2, BRS G3, BRS G4 e BRS Anahi) e níveis de salinidade do solo com as seguintes condutividades elétricas: $0,6 \mathrm{dS} \mathrm{m}^{-1}$; $1,2 \mathrm{dS} \mathrm{m}^{-1} ; 1,8 \mathrm{dS} \mathrm{m}^{-1} ; 2,4 \mathrm{dS} \mathrm{m}^{-1} ;$ e $3,0 \mathrm{dS} \mathrm{m}^{-1}$. Para a caracterização da qualidade fisiológica, foram realizados testes de germinação, primeira contagem de germinação, índice de velocidade de germinação, comprimento de radícula, condutividade elétrica das sementes, emergência, índice de velocidade de emergência e massa seca de plântulas. BRS Seda, BRS G2 e BRS G3, cultivadas sob níveis salinos, apresentam sementes com melhores qualidades fisiológicas, demonstrando maior tolerância a condições de estresse salino. BRS Seda e BRS G2 toleram níveis salinos de até $2,4 \mathrm{dS} \mathrm{m}^{-1}$, enquanto BRS G3 tolera até $1,8 \mathrm{dS} \mathrm{m}^{-1}$. BRS G4 e BRS Anahi têm a qualidade fisiológica de suas sementes comprometida com o aumento da salinidade do solo, durante sua produção.

PALAVRAS-CHAVE: Sesamum indicum L.; estresse salino; qualidade fisiológica de sementes.

generation of income and employment, constituting an alternative of exploitation (Magalhães et al. 2013).

The largest sesame producers are India and China, accounting for $70 \%$ of the world production. Brazil shows an average yield of $13.000 \mathrm{t}$, with approximately $650 \mathrm{~kg} \mathrm{ha}^{-1}$ (Arriel et al. 2005, Guimarães et al. 2013).

1. Manuscript received in Apr./2018 and accepted for publication in Aug./2018 (http://dx.doi.org/10.1590/1983-40632018v4852615). 2. Universidade Federal da Paraíba, Areia, PB, Brasil. E-mail/ORCID: jaksonnobrega@hotmail.com/0000-0002-9538-163X.

3. Universidade Federal de Campina Grande, Pombal, PB, Brasil.E-mail/ORCID: kilsonlopes@gmail.com/ 0000-0003-1577-5901, agrosantos@hotmail.com/0000-0003-3058-007X,je.an_93@hotmail.com/0000-0001-7603-4782, geovanisoareslima@gmail.com/0000-0001-9960-1858.

4. Universidade Federal de Pelotas, Pelotas, RS, Brasil.E-mail/ORCID: joseano2017-123@hotmail.com/0000-0002-8144-4329. 
The Brazilian semi-arid region is characterized by high levels of salts in the soil and water used in irrigation, which may originate from the soil source material, due to inadequate and excessive use of irrigation and mineral fertilizers, inefficient drainage and environmental conditions (low rainfall and high evapotranspiration), which directly affect the yield of crops, resulting in losses in the production quality and quantity (Gondim et al. 2010, Pedrotti et al. 2015).

The osmotic effect caused by salts reduces the capacity of water absorption by plants, in addition to the effects of some specific ions, particularly $\mathrm{Na}^{+}$and $\mathrm{Cl}^{-}$, which lead to functional disorders and injuries, especially in the leaves, culminating in modifications in physiological and metabolic processes, which may affect the crop yield quality and final quality of the product (Nobre et al. 2013).

The physiological quality of seeds is an aspect of great relevance for the establishment of a crop. Physical, physiological, genetic and sanitary aspects related to seed quality are considered as attributes that determine the value of the sowing and, consequently, the establishment of the crop, a basic factor to ensure a successful production (Barrozo et al. 2012). Environmental conditions and techniques adopted during the production of seeds may influence their physiological quality, and their vigor may or may not be affected more intensely (Marcos Filho 2013), especially if subjected to stress conditions.

The effect of saline stress during the seed production phase may cause losses in transport and accumulation of reserves, resulting in low quality seeds and vigor. Thus, the quality of the seed will reflect on the stand of plants, thus affecting the performance of the plant, both from the nutritional point of view as in quality (Silva et al. 2016a, Souza Neta et al. 2016).

In this context, this study aimed to evaluate the physiological quality of sesame seeds (Sesamum indicum L.) produced under levels of soil salinity.

\section{MATERIAL AND METHODS}

The study was conducted at the Universidade Federal de Campina Grande, in Pombal, Paraíba state, Brazil (06 46 ' 13' S, 37 $48^{\circ}$ '06" W and $242 \mathrm{~m}$ of altitude). According to the Köppen classification, the predominant climate is Bsh (semi-arid), hot and dry, with precipitation of approximately $700 \mathrm{~mm}$ year $^{-1}$.
The seeds were produced in a protected environment from March to June 2016, at the experimental area of the Universidade Federal de Campina Grande, in Campina Grande, Paraíba state, Brazil.

Seeds of five sesame cultivars (BRS Seda, BRS G2, BRS G3, BRS G4 and BRS Anahi) were produced under five levels of electrical conductivity $\left(0.6 \mathrm{dS} \mathrm{m}^{-1}, 1.2 \mathrm{dS} \mathrm{m}^{-1}, 1.8 \mathrm{dS} \mathrm{m}^{-1}, 2.4 \mathrm{dS} \mathrm{m}^{-1}\right.$ and $3.0 \mathrm{dS} \mathrm{m}^{-1}$ ) in the soil saturation extract, totaling 25 lots of seeds to be evaluated, following a completely randomized design, in a $5 \times 5$ factorial scheme, with three replicates.

The soil salinity levels were obtained by the dissolution of sodium chloride $(\mathrm{NaCl})$, calculated according to the treatments, considering the initial level of soil salinity $\left(0.6 \mathrm{dS} \mathrm{m}^{-1}\right)$, soil weight per pot $(21 \mathrm{~kg})$ and saturation percentage (30\%).

The experiment was conducted in pots with capacity for $20 \mathrm{dm}^{3}$, filled with Eutrophic Quartzarenic Neosol, and arranged at spacings of $1.0 \mathrm{~m}$ in the row and 0.8 between plants. NPK fertilization was carried out: phosphorus was applied before planting, in the form of $\mathrm{P}_{2} \mathrm{O}_{5}$, as single superphosphate, at a dose of $300 \mathrm{mg} \mathrm{kg}^{-1}$ of soil; potassium application was split into two portions, using potassium chloride at the reference dose of $150 \mathrm{mg} \mathrm{kg}^{-1}$ of $\mathrm{K}_{2} \mathrm{O}$; and nitrogen was applied as urea at a dose of $100 \mathrm{mg} \mathrm{kg}^{-1}$ of soil, split into three applications. Fertilizations were conducted according to the recommendations for fertilization in pots by Novais (1991).

Irrigations were carried out daily using publicsupply water, and the water depth to be applied was estimated based on the water balance in the root zone, by subtracting the volume drained from the volume applied in the previous irrigation, according to the following formula: $\mathrm{VI}=\mathrm{VA}-\mathrm{VD}$, where: $V I$ is the volume to be applied by irrigation; $V A$ the water volume applied; and $V D$ the water volume drained.

Seeds were harvested at 110 days after the establishment of the plants, pre-cleaned and placed in plastic bags properly classified into lots, according to the studied treatments. Then, the lots were sent to physiological quality evaluation. The following variables were determined:

- Germination: four replicates of 50 seeds from each treatment were planted in Gerbox-type acrylic boxes, on two sheets of blotter paper moistened with distilled water in a volume equivalent to 2.5 times the substrate dry weight, and placed in a Biochemical 
Oxygen Demand (BOD) germination chamber at the alternate temperature of $20-30{ }^{\circ} \mathrm{C}$, under a 12 -h photoperiod. Evaluations were conducted from the third to the sixth day after sowing. Germinated seeds were considered as those with two leaf primordia and developed radicle. Germination data were expressed in percentage of normal seedlings (Brasil 2009);

- First germination count: it corresponded to the percentage of normal seedlings quantified on the first day of count, performed on the third day of the standard germination test;

- Germination speed index: determined along with the germination test, by daily counts of normal seedlings along the duration of the germination test, calculated using the formula proposed by Maguire (1962):

$$
\mathrm{GSI}=\frac{\mathrm{G} 1}{\mathrm{~N} 1}+\frac{\mathrm{G} 2}{\mathrm{~N} 2}+\cdots+\frac{\mathrm{Gn}}{\mathrm{Nn}}
$$

where $G 1, G 2, G n$ are the number of seeds germinated at the first, second and last day of count, respectively; and $N 1, N 2, N n$ the number of days from the first, second and last day of count, respectively;

- Electrical conductivity: determined using four replicates of 50 seeds, from each treatment, previously weighed on a precision analytical scale and then placed to soak in a $100-\mathrm{mL}$ beaker containing $50 \mathrm{~mL}$ of deionized water, for $24 \mathrm{~h}$, at $20 \pm 3{ }^{\circ} \mathrm{C}$. After the soaking period, the electrical conductivity of the solution was determined by reading in a conductivity meter (mCA-150/MS Tecnopon), with results expressed in $\mu \mathrm{S} \mathrm{cm} \mathrm{g}^{-1}$ (Barbosa et al. 2012);

- Radicle length: four subsamples with 10 seeds from each treatment were placed in Gerboxtype boxes, on blotter paper moistened with distilled water in a volume equivalent to 2.5 times its dry weight. The boxes were placed in a BOD-type germinator at the temperature of $25^{\circ} \mathrm{C}$ and inclined at $45^{\circ}$ (Cardoso et al. 2009). The evaluation was carried out at four days, and radicle was measured using a digital caliper. The length was obtained by summing the measurements of the radicle of each normal seedling, in each subsample, and dividing the total value by the number of normal seedlings measured. The results were expressed in mm plant ${ }^{-1}$;

- Emergence: the test was conducted in a protected environment, using four replicates of 50 seeds, which were sown on plastic trays containing only soil as substrate. Daily counts of the emerged seedlings were carried out until the fifteenth day, and the results were expressed in percentage of normal seedlings emerged;

- Emergence speed index: determined during the emergence test and corresponding to daily counts of normal seedlings emerged along all tests, calculated according to Maguire (1962):

$$
\mathrm{ESI}=\frac{\mathrm{E} 1}{\mathrm{~N} 1}+\frac{\mathrm{E} 2}{\mathrm{~N} 2}+\cdots+\frac{\mathrm{En}}{\mathrm{Nn}}
$$

where $E 1, E 2, E n$ are the number of normal seedlings emerged on the first, second and last days of count, respectively; and $N 1, N 2, N n$ the number of days of the first, second and last day of count, respectively;

- Seedling dry matter: normal seedlings, obtained at the end of the emergence test, were removed from the trays, placed in Kraft paper bags and maintained in a forced-air oven regulated at $65{ }^{\circ} \mathrm{C}$, until constant weight (Aguiar et al. 2014). After drying, the seedlings were weighed using an analytical scale $(0.01 \mathrm{~g}$ precision), and the total weight of each replicate was divided by the number of normal seedlings, to obtain the mean dry matter per seedling, expressed in g plant $^{-1}$.

The data were subjected to analysis of variance $(\mathrm{p}<0.05)$ and, when significant, subjected to polynomial regression analysis for the factor salinity and Tukey test for the factor cultivars. The statistical procedures were conducted using the Sisvar ${ }^{\circledR}$ software (Ferreira 2014).

\section{RESULTS AND DISCUSSION}

The summary of the analysis of variance for germination, first germination count, germination speed index, radicle length, electrical conductivity, seedling emergence, emergence speed index and seedling dry matter is presented in Table 1. All analyzed variables were significantly affected by the interaction between cultivars and salinity, except for emergence, emergence speed index and seedling dry matter.

Aquadratic effect was found for the germination of seeds of the BRS G2 and BRS G3 cultivars, and maximum values (96.5\% and $98.8 \%$ ) were observed when seeds were produced at the salinity level of $1.8 \mathrm{dS} \mathrm{m}^{-1}$. On the other hand, the BRS Seda cultivar showed the highest germination $(97 \%)$ at the electrical conductivity of the saturation extract (ECse) of $2.2 \mathrm{dS} \mathrm{m}^{-1}$ (Figure 1a). 
Table 1. Summary of the analysis of variance for germination (G\%), first germination count (FGC), germination speed index (GSI), radicle length $(\mathrm{RL})$, electrical conductivity $(\mathrm{EC})$, seedling emergence $(\mathrm{E} \%)$, emergence speed index (ESI) and seedling dry matter (SDM) of sesame (Sesamum indicum L.) seeds produced under different salinity levels.

\begin{tabular}{lrcccccccc}
\hline $\begin{array}{l}\text { Source of } \\
\text { variation }\end{array}$ & \multirow{2}{*}{ DF } & \multicolumn{9}{c}{ Average squares } \\
\cline { 3 - 10 } & & G\% & FGC & GSI & RL & EC & E\% & ESI & SDM \\
\hline Cultivar (C) & 4 & $314.80^{*}$ & $1,652.24^{*}$ & $1.96^{*}$ & $28.23^{*}$ & $5,713.88^{*}$ & $67.54^{\text {ns }}$ & $2.29^{\text {ns }}$ & $0.13^{*}$ \\
Salinity (S) & 4 & $154.80^{*}$ & $2,143.44^{*}$ & $1.55^{*}$ & $119.06^{*}$ & $28,098.99^{*}$ & $543.79^{*}$ & $9.43^{\text {ns }}$ & $0.05^{\text {ns }}$ \\
C x S & 16 & $219.10^{*}$ & $1,942.74^{*}$ & $1.70^{*}$ & $11.13^{*}$ & $4,839.38^{*}$ & $280.21^{\text {ns }}$ & $4.91^{\text {ns }}$ & $0.05^{\text {ns }}$ \\
Residue & 75 & 57.22 & 109.49 & 0.23 & 1.02 & 260.93 & 205.25 & 4.25 & 0.04 \\
\hline Total & 99 & - & - & - & - & - & - & - & - \\
\hline CV $(\%)$ & & 8.28 & 14.92 & 8.95 & 15.94 & 12.97 & 18.74 & 24.20 & 38.63 \\
\hline
\end{tabular}

${ }^{\text {ns }}$ Not significant; * significant at $5 \%$, by the $\mathrm{F}$ test.

Declines in the germination of sesame cultivars may be associated with the quality losses occurred during their production, because salinity affects the soil water potential, leading to the accumulation of salt ions in plant tissues, what results in nutritional imbalance and, consequently, affects the embryo quality. These damages are caused by the absorption of toxic ions, particularly $\mathrm{Na}^{+}$and $\mathrm{Cl}^{-}$, along with the water through the roots, in amounts which cannot be compartmentalized by the plant in the vacuole (Araújo et al. 2014). Because of that, there is an

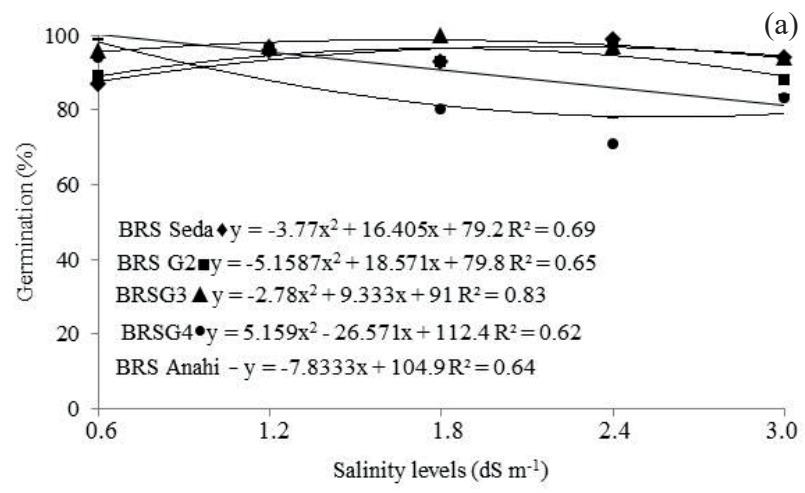

(a)

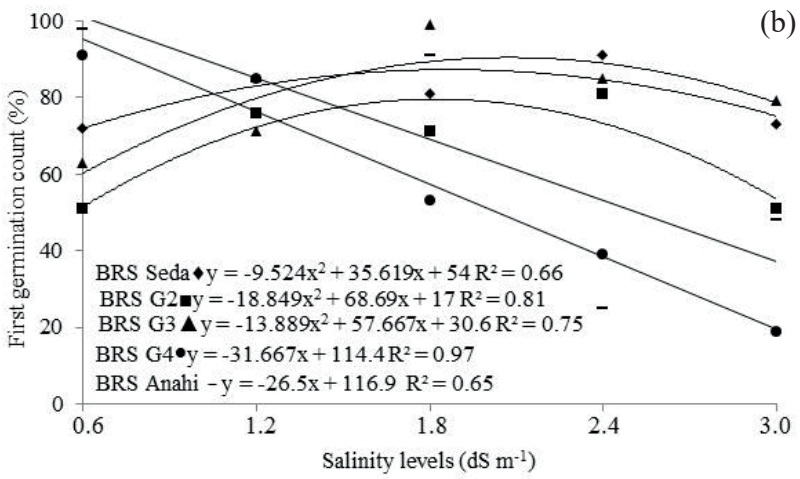

increase in the amount of salts in the cytoplasm, which ultimately inhibits the activity of enzymes in several metabolic pathways (Prisco et al. 2016).

Sensitivity to salinity depends on the studied cultivar. For the BRS G4 and BRS Anahi cultivars, the highest germination values $(98.3 \%$ and $100 \%)$ were obtained at the ECse of $0.6 \mathrm{dS} \mathrm{m}^{-1}$, and a drastic reduction occurred in germination as soil salinity levels increased (Figure 1a). Similar results were obtained by Azevedo et al. (2003), who observed a reduction in the germination percentage of sesame seeds subjected to $\mathrm{NaCl}$ concentrations, during germination.

The behavior of vigor in sesame seeds, characterized by the first germination count, produced under different saline levels, was similar to that found for viability. A quadratic regression equation described the first germination count data of the BRS Seda, BRS G2 and BRS G3 cultivars (Figure 1b), whereas first germination count values tended to decrease linearly for BRS G4 and BRS Anahi, with the increment in soil salinity, during

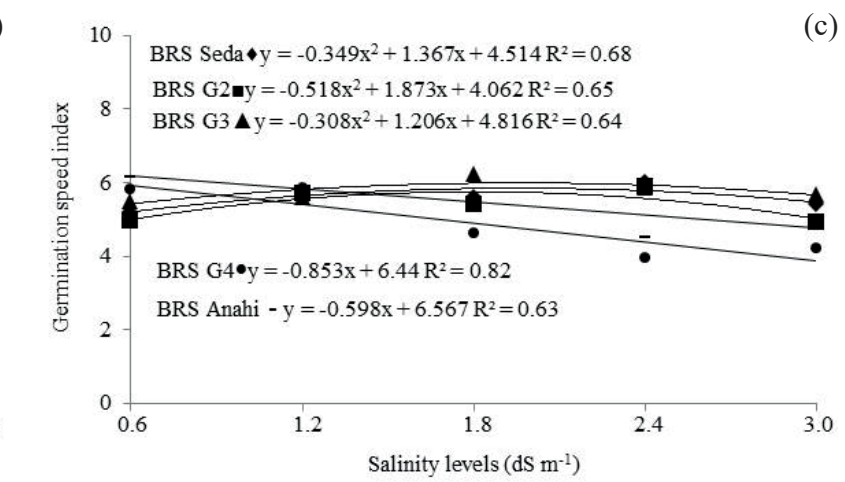

(c)

Figure 1. Germination (a), first germination count (b) and germination speed index (c) of sesame seeds produced at different salinity levels.

e-ISSN 1983-4063 - www.agro.ufg.br/pat - Pesq. Agropec. Trop., Goiânia, v. 48, n. 3, p. 280-286, Jul./Sep. 2018 
their production. Conversely, the BRS Seda, BRS G2 and BRS G3 cultivars obtained maximum values of $87 \%, 79 \%$ and $90 \%$, respectively, at the levels of $1.9 \mathrm{dS} \mathrm{m}^{-1}, 1.8 \mathrm{dS} \mathrm{m}^{-1}$ and $2.1 \mathrm{dS} \mathrm{m}^{-1}$. Such difference in the quality of sesame seeds was also reported by Jesus et al. (2015), who evaluated the quality of seeds of different cultivars and observed that the BRS G2 and Seridó were superior to BRS G4 and BRS Seda.

Seed vigor, characterized by the germination speed index, for the different sesame cultivars produced under different salt concentrations, is shown in Figure 1c. The physiological behavior of these seeds was similar to the responses found for total germination (Figure 1a) and first germination count (Figure 1b), in which the data of the BRS Seda and BRS G3 cultivars were described by a quadratic equation, with maximum values at the salinity level of $2.0 \mathrm{dS} \mathrm{m}^{-1}$, whereas the seeds of the BRS G2 cultivar showed maximum vigor when produced at a salinity of $1.8 \mathrm{dS} \mathrm{m}^{-1}$.

The results obtained (Figure 1c) clearly demonstrate the trend of reduction in seed vigor, as soil salinity increased. This effect is related to the stress imposed on plants during the production, in which the high concentration of toxic ions leads to a series of alterations in osmotic and ionic homeostasis, culminating in modifications in the physiological and metabolic processes in the embryo tissues, including effects on cell division and differentiation, activity of enzymes which act in metabolic processes and on the capacity of plants to acquire and translocate nutrients (Dantas et al. 2011).

For seeds of the BRS G4 and BRS Anahi cultivars, a decreasing linear effect on germination speed index was observed when the soil salinity increased during their production (Figure 1c), indicating that there was a deleterious effect of the salts when the seeds were produced under salt stress conditions. It should be pointed out that seeds with low vigor tend to have a more prolonged germination process, which is slow and unsynchronized (Marcos Filho 2005). Silva et al. (2016a), evaluating the physiological quality of sesame seeds produced under water stress conditions, found that the germination speed was greatly affected by the stress.

The radicle length (Figure $2 \mathrm{a}$ ) decreased linearly for all cultivars, as salinity levels increased. This effect may have resulted from the reduction in the osmotic potential of the soil, which led to a restriction on the water potential, consequently affecting the water absorption by the seed and its capacity of assimilation and translocation of nutrients to compose the store reserves, leading to losses in quality and vigor (Busanello 2015).

Water deficit is a factor directly related to plant growth, because of the functions performed by the water, such as capacity to solubilize elements that are essential for development, facilitating their mobility inside the plant, and for being a medium which governs several chemical reactions that occur in plants (Taiz et al. 2017). Brito et al. (2015), evaluating the initial development of castor bean under different salinity levels, observed deleterious effects of salt stress on primary root length, due to the increase in salt concentration. The same trend was also observed by Andréo-Souza et al. (2010), in jatropha seeds.

Regarding electrical conductivity, a quadratic equation described the data of seeds of the BRS Seda and BRS G2 cultivars (Figure 2b), and their minimum value was found at soil salinity levels of approximately $2.0 \mathrm{dS} \mathrm{m}^{-1}$ and $1.8 \mathrm{dS} \mathrm{m}^{-1}$, respectively.
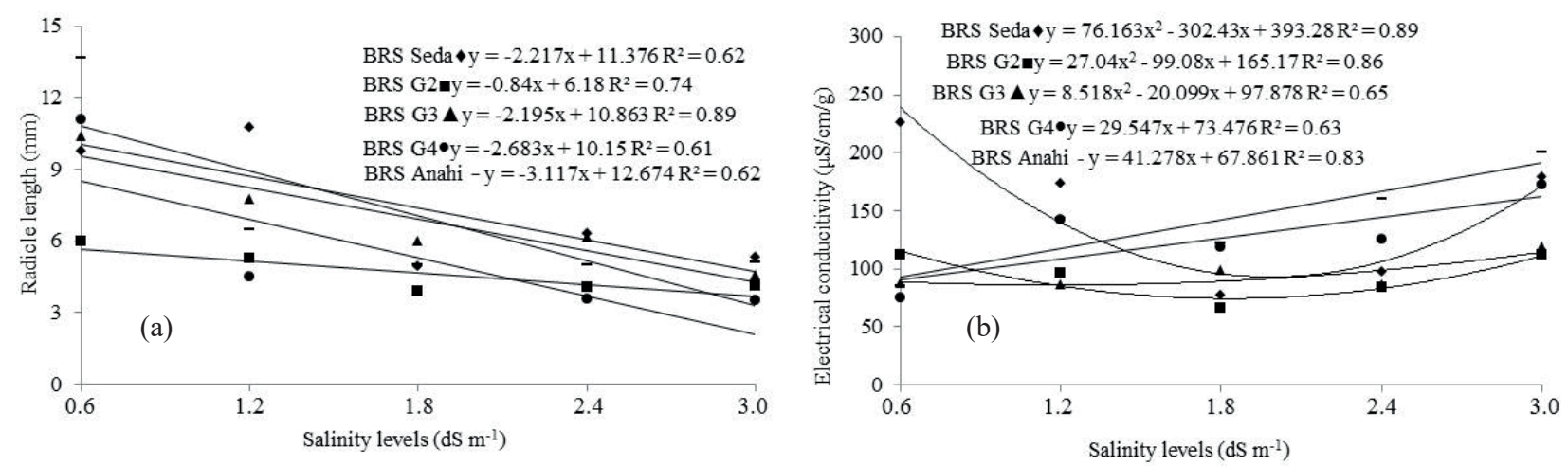

Figure 2. Seedling radicle length (a) and electrical conductivity (b) of sesame seeds produced at different salinity levels. 
Table 2. Mean values for seedling dry matter of sesame cultivars produced at different salinity levels.

\begin{tabular}{cccccc}
\hline \multicolumn{5}{c}{ Seedling dry matter $\left(\right.$ g plant $\left.^{-1}\right)$} \\
\hline \multirow{2}{*}{ Salinity $\left(\mathrm{dS} \mathrm{m}^{-1}\right)$} & \multicolumn{5}{c}{ Cultivar } \\
\cline { 2 - 6 } & BRS Seda & BRS G2 & BRS G3 & BRS G4 & BRS Anahi \\
\hline 0.6 & $0.81 \mathrm{a}^{*}$ & $0.41 \mathrm{ab}$ & $0.50 \mathrm{ab}$ & $0.59 \mathrm{ab}$ & $0.37 \mathrm{~b}$ \\
1.2 & $0.54 \mathrm{a}$ & $0.46 \mathrm{a}$ & $0.53 \mathrm{a}$ & $0.46 \mathrm{a}$ & $0.52 \mathrm{a}$ \\
1.8 & $0.78 \mathrm{a}$ & $0.84 \mathrm{a}$ & $0.53 \mathrm{a}$ & $0.48 \mathrm{a}$ & $0.54 \mathrm{a}$ \\
2.4 & $0.72 \mathrm{a}$ & $0.54 \mathrm{a}$ & $0.41 \mathrm{a}$ & $0.62 \mathrm{a}$ & $0.61 \mathrm{a}$ \\
3.0 & $0.66 \mathrm{a}$ & $0.50 \mathrm{a}$ & $0.55 \mathrm{a}$ & $0.36 \mathrm{a}$ & $0.60 \mathrm{a}$ \\
\hline
\end{tabular}

* Means followed by the same letter in the rows do not differ by the Tukey test $(\mathrm{p}<0.05)$.

From this level on, electrical conductivity values in the seeds tended to increase when the cultivars were produced under conditions of greater stress. The BRS G3, BRS G4 and BRS Anahi cultivars showed a greater loss of leachates to the solution at the salinity level of $3 \mathrm{dS} \mathrm{m}^{-1}$, in the soil saturation extract.

The greater loss of leachates observed in seeds produced at higher levels of soil salinity may be a consequence of the deleterious effects of the salts, which cause alterations in homeostasis and affect the physiological quality of the seeds, resulting in a greater disorganization of cell membranes. Thus, the deterioration of the seed begins with the disorganization of the internal tissues, affecting the seed quality and vigor. Seed quality is inversely associated with the deterioration process, which reduces quality, vigor and viability (Siadat et al. 2012).

Seedling emergence was only significantly affected by salinity, and its values were described by a quadratic model. The highest percentage of emerged seedlings was found at an ECse of $2.0 \mathrm{dS} \mathrm{m}^{-1}(80.6 \%)$, and the values decreased as salinity increased (Figure 3). The average index of

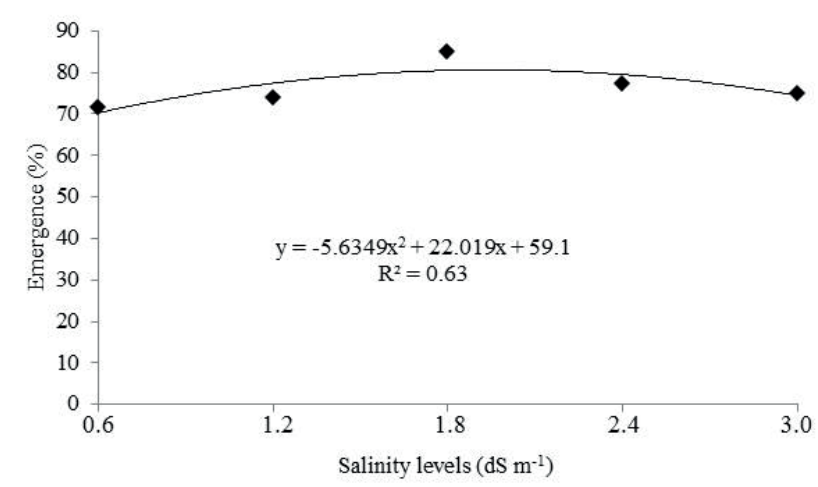

Figure 3. Emergence of sesame seedlings produced at different salinity levels. seedling emergence speed was 8.5 , regardless of soil salinity, and the final percentage was reduced by the higher ECse levels. Thus, seeds produced at higher ECse levels tend to be less vigorous, what may be due to the accumulation of toxic ions, particularly $\mathrm{Na}^{+}$ and $\mathrm{Cl}^{-}$(Souza Neta et al. 2016), causing alterations in the seed biochemical processes.

The values for seedling dry matter did not change much among the sesame cultivars at each applied salinity level, except for BRS Anahi, which showed the lowest values of seedling dry matter at $0.6 \mathrm{dSm}^{-1}$, significantly differing from BRS Seda (Table 2). Such behavior may be considered as a strategy of the seedling to accumulate more reserves at higher salinity levels. According to Silva et al. (2016b), plants at different stages of development, upon exposure to salt stress conditions, tend to use strategies such as the accumulation of reserves to overcome the effects caused by salinity.

\section{CONCLUSIONS}

1. The BRS Seda, BRS G2 and BRS G3 sesame cultivars, grown at different levels of salinity, show seeds with a better physiological quality when produced at salinity levels of up to $2.0 \mathrm{dS} \mathrm{m}^{-1}$;

2. The BRS G4 and BRS Anahi cultivars are sensitive to the effects of salinity during the production of their seeds, which tend to present a lower physiological quality as salinity increases, during their production.

\section{REFERENCES}

AGUIAR, R. S. et al. Extração de mucilagem e substratos no desenvolvimento de plântulas de maracujazeiroamarelo. Semina: Ciências Agrárias, v. 35, n. 2, p. 605612, 2014. 
ANDRÉO-SOUZA, Y. et al. Efeito da salinidade na germinação de sementes e no crescimento inicial de mudas de pinhão-manso. Revista Brasileira de Sementes, v. 32, n. 2, p. 83-92, 2010.

ARAÚJO, L. F. et al. Alocação de íons e crescimento de cajueiro anão-precoce com água salina no campo. Revista Brasileira de Engenharia Agrícola e Ambiental, v. 18, suppl., p. 534-538, 2014.

ARRIEL, N. H. C. et al. Situação atual e perspectivas da cultura do gergelim no Brasil. Campina Grande: Embrapa, 2005.

AZEVEDO, M. R. Q. A. et al. Germinação e vigor no desenvolvimento inicial do gergelim: efeito da salinidade da água de irrigação. Revista Brasileira de Produtos Agroindustriais, v. 5, n. 2, p. 169-174, 2003.

BARBOSA, R. M. et al. Teste de condutividade elétrica em sementes de maracujazeiro-amarelo. Revista Brasileira de Fruticultura, v. 34, n. 2, p. 646-651, 2012.

BARROZO, L. M. et al. Qualidade sanitária de sementes de Arachis hypogaea L. em função de velocidades de arranquio e recolhimento. Biocience Journal, v. 28, n. 4, p. 573-579, 2012.

BRASIL. Ministério da Agricultura, Pecuária e Abastecimento. Regras para análise de sementes. Brasília, DF: MAPA/ACS, 2009.

BRITO, K. Q. D. et al. Efeito da salinidade na germinação e desenvolvimento inicial da mamona 'BRS Energia'. Revista Verde de Agroecologia e Desenvolvimento Sustentável, v. 10, n. 4, p. 17-20, 2015.

BUSANELLO, R. L. Efeito da salinidade na germinação e vigor de sementes de arroz puitá inta cl sob concentrações crescentes de $\mathrm{NaCl}$. 2015. $36 \mathrm{f}$. Monografia do curso de Agronomia - Universidade Federal de Santa Maria, Santa Maria, 2015.

CARDOSO, D. L. et al. Diversidade genética e parâmetros genéticos relacionados à qualidade fisiológica de sementes em germoplasma de mamoeiro. Revista Ceres, v. 56, n. 5, p. $572-579,2009$.

DANTAS, C. V. S. et al. Influência da salinidade e déficit hídrico na germinação de sementes de Carthamus tinctorius L. Revista Brasileira de Sementes, v. 33, n. 3, p. 574-582, 2011.

FERREIRA, D. F. Sisvar: a guide for its bootstrap procedures in multiple comparisons. Ciência e Agrotecnologia, v. 38, n. 2, p. 109-112, 2014.

GONDIM, F. A. et al. Pretreatment with $\mathrm{H}_{2} \mathrm{O}_{2}$ in maize seeds: effects on germination and seedling acclimation to salt stress. Brazilian Journal of Plant Physiology, v. 22, n. 2, p. 103-112, 2010.

GUIMARÃES, R. C. A. et al. Sesame and flaxssed oil: nutritional quality and effects on serum lipids and glucose in rats. Food Science and Technology, v. 33, n. 1, p. 209217, 2013.

JESUS, L. L. et al. Teste de tetrazólio para sementes de Sesamum indicum. Revista de Ciências Agrárias, v. 38, n. 3, p. 422-428, 2015.

MAGALHÃES, I. D. et al. Viabilidade do consórcio mamona-gergelim para a agricultura familiar no semiárido paraibano: influência de diferentes épocas de plantio. Revista Brasileira de Agroecologia, v. 8, n. 1, p. 57-65, 2013.

MAGUIRE, J. D. Speed of germination-aid in selection and evaluation for seedling emergence vigor. Crop Science, v. 2, n. 2, p. 176-177, 1962.

MARCOS FILHO, J. Fisiologia de sementes de plantas cultivadas. Piracicaba: Fealq, 2005.

MARCOS FILHO, J. Potencial fisiológico da semente de soja. Informativo Abrates, v. 23, n. 1, p. 21-24, 2013.

NOBRE, R. G. et al. Emergência, crescimento e produção da mamoneira sob estresse salino e adubação nitrogenada. Revista Ciência Agronômica, v. 44, n. 1, p. 76-85, 2013.

NOVAIS, R. F. et al. Ensaio em ambiente controlado. In: OLIVEIRA, A. J. (Ed.). Métodos de pesquisa em fertilidade do solo. Brasília, DF: Embrapa-SEA, 1991. p. 189-253.

PEDROTTI, A. et al. Causas e consequências do proceso de salinização dos solos. Revista Eletrônica em Gestão, Educação e Tecnologia Ambiental, v. 19, n. 2, p. 13081324, 2015.

PRISCO, J. T. et al. Physiology and biochemistry of plants growing under salt stress. In: GHEYI, H. R. et al. (Ed.). Manejo da salinidade na agricultura: estudos básicos e aplicados. Fortaleza: INCTSal, 2016. p. 163-180.

SIADAT, S. A. et al. Effect of seed priming on antioxidant activity and germination characteristics of maize seeds under different aging treatments. Research Journal of Seed Science, v. 5, n. 2, p. 51-62, 2012.

SILVA, R. C. et al. Vigor de sementes de milho: influência no desenvolvimento de plântulas em condições de estresse salino. Revista Ciência Agronômica, v. 47, n. 3, p. 491499, 2016 b.

SILVA, R. T. et al. Physiological quality of sesame seeds produced from plants subjected to water stress. Revista Ciência Agronômica, v. 47, n. 4, p. 643-648, 2016a.

SOUZA NETA, M. L. et al. Residual effect of bur gherkin seed treatement with biostimulant under salt stress. Journal of Seed Science, v. 38, n. 3, p. 219-226, 2016.

TAIZ, L. et al. Fisiologia e desenvolvimento vegetal. 6. ed. Porto Alegre: Artmed, 2017. 